$12-21-2021$

\title{
Book Review: Scorched Earth: Environmental Warfare as a Crime Against Humanity and Nature
}

Jeremy Ritzer

Gratz College; Singapore American School

Follow this and additional works at: https://digitalcommons.usf.edu/gsp

\section{Recommended Citation}

Ritzer, Jeremy (2021) "Book Review: Scorched Earth: Environmental Warfare as a Crime Against Humanity and Nature," Genocide Studies and Prevention: An International Journal: Vol. 15: Iss. 3: 123-126.

DOI:

https://doi.org/10.5038/1911-9933.15.3.1854

Available at: https://digitalcommons.usf.edu/gsp/vol15/iss3/14

This Book Review is brought to you for free and open access by the Open Access Journals at Digital Commons @ University of South Florida. It has been accepted for inclusion in Genocide Studies and Prevention: An International Journal by an authorized editor of Digital Commons @ University of South Florida. For more information, please contact digitalcommons@usf.edu. 


\title{
Book Review: Scorched Earth: Environmental Warfare as a Crime Against Humanity and Nature
}

\author{
Jeremy Ritzer \\ Gratz College; Singapore American School \\ Melrose Park, Philadelphia, U.S.A.; Singapore
}

\author{
Scorched Earth: Environmental Warfare as a Crime Against Humanity and Nature \\ Emmanuel Kreike \\ Princeton, Princeton University Press, 2021 \\ 538 Pages; Price: \$39.95 Hardcover
}

Reviewed by Jeremy Ritzer

Gratz College; Singapore American School

The subtitle of Emmanuel Kreike's Scorched Earth foreshadows the goal of this impressive and comprehensive contribution to the field. His goal is to chip away at the Nature-Culture dichotomy that he argues drives, and limits, much of the analysis that is produced of historical, and modern, warfare. Kreike uses the concept of environcide, which he defines as "intentionally or unintentionally damaging, destroying, or rendering inaccessible environmental infrastructure," 1 and argues that the traditional assumptions about nature and culture in the study of warfare obscure the importance of the natural world in determining who lives and who dies. For the field of genocide studies, Kreike's work promotes the analysis of mass violence and potentially genocidal conflicts by looking not simply at actions taken by perpetrators directly against victims, but also at a litany of actions that perpetrators might take that could reasonably result in mass death, joining those in the field who promote a shift in the definition of genocide that includes actions that do not simply meet the definition of dolus specialis to also those that demonstrate dolus eventualis. While confiscating food and burning fields may not fit our current understanding of genocidal acts, they can certainly have the same eventual outcome as the use of machine guns and poison gas. And, recent scholars of risk factors do note the importance of "crises, resource scarcity, population pressure, natural disasters" as increasing the likelihood of genocide. ${ }^{2}$

An interesting note here is that confiscation of food, environmental destruction including the spreading of vegetable contagions and toxins meant to kill animals, were part of the first definitions of genocide developed by Raphaël Lemkin, but they specifically removed by diplomats during the drafting of the treaty. ${ }^{3}$ While Lemkin did not directly address what later came to be called ecocide (a term that was first used in 1970), some scholars see clear hints of his sympathies in his concern for cultural destruction and in his identification of "deprivation of livelihood" as a method and technique of genocide. ${ }^{4}$ Kreike's work here can be very much seen to be in the spirit of Lemkin, salvaging key components of Lemkin's original conception of

\footnotetext{
${ }^{1}$ Emmanuel Kreike, Scorched Earth: Environmental Warfare as a Crime Against Humanity and Nature (Princeton: Princeton University Press, 2021), 3.

2 Hollie Nyseth Brehm, "Re-Examining Risk Factors of Genocide," Journal of Genocide Research 19, no.1 (2017), 66, accessed November 10, 2021, http://dx.doi.org/10.1080/14623528.2016.1213485.

3 Douglas Irvin-Erickson, Raphaël Lemkin and the Concept of Genocide (Philadelphia: University of Pennsylvania Press, 2017), 46, 92.

4 Martin Crook and Damien Short, "Marx, Lemkin and the Genocide-Ecocide Nexus," The International Journal of Human Rights 18 no.3 (2014), 305, 307, accessed November 1, 2021, https:// doi.org/10.1080/13642987.2014.914703.
} 
genocide. ${ }^{5}$ The book also contributes to a growing movement in the field of genocide studies, which seeks to address the serious questions of ecocide, environmental destruction, and climate change-both in terms of these as threats to human life, and in that the world's ecological wellbeing has inherent value. ${ }^{6}$ What distinguishes Kreike's study from mainstream genocide studies, from Lemkin all the way up to the present day, is his focus on the importance of the limitations of the Nature-Culture nexus, especially when we attempt to consider the importance of prediction and prevention in our field. ${ }^{7}$

The Nature-Culture dichotomy that Kreike takes issue with has its roots in a view of the world through other prevailing dichotomies, such as non-Western and Western, and modern and pre-modern. Traditionally, the non-Western and pre-modern societies were assumed to be more associated with Nature, whereas the Western and modern societies were more associated with Culture (because of these societies' ability to domesticate and control Nature). ${ }^{8}$ Many scholars have already commented on the problem with these simplistic, and romantic, views of the past, and of bright line distinctions between perpetrators and victims. For Kreike, breaking down these assumptions helps us to better understand the mechanisms that have been, and are being, used to create conditions in which mass violence can occur.

Kreike supports his argument with historical case studies from the 16th to 20th centuries in support. From Holland of the 1500s, to Angola and Namibia in the early 1900s, Kreike demonstrates that humans have been regularly shaping our environment, and that warfare has historically targeted these human creations in order to harm populations. For example, in the Dutch Revolt (or War of Flanders) against Spanish Hapsburg regime from 1568 to 1648, Kreike shows that attacks on "Holland's environmental infrastructure" were common. This involved not only more traditional acts of total war such as burning homes, farms, and villages, but also the opening of sluices and breaching of dikes in order to cause massive flooding. ${ }^{9}$ Whomever controlled these key pieces of water controlled the "Water Wolf" that perpetually plagued low-lying Holland. This infrastructure controlled the flow of water, allowing them to flood lands held by their opponents, driving the enemy from that land or denying them the resources it provided. While much work has been done on scorched earth tactics in North America from the 1600s to the 1800s, Kreike also shows how such actions were also widely used in Atlantic Africa during the same era. Warfare amongst African groups, in addition to deforestation and mining, transformed the Gold Coast of Africa into the slave coast between the 1600s and 1700s. ${ }^{10}$ Portuguese invasions of Angola in 1904 and 1907 led to such destruction of resources that each was followed by famine. ${ }^{11}$ Thus, in each of the examples that Kreike provides, including others such as the American West and Indonesia in the 1800s, he

${ }^{5}$ On the Soviets' sensitivity to having any reference to famine or hunger in the Genocide Convention, see Anton WeissWendt, The Soviet Union and the Gutting of the UN Genocide Convention (Madison: University of Wisconsin Press, 2017).

6 See Mark Levene, "The Holocaust Paradigm as Paradoxical Imperative in the Century of Anthropogenic Omnicide," Genocide Studies and Prevention (forthcoming); Damien Short, Redefining Genocide: Settler Colonialism, Social Death and Ecocide (London: Zed Books, 2016); Alex Alvarez, "Borderlands, Climate Change, and the Genocidal Impulse," Genocide Studies International 10, no. 1 (2016), 27-36, accessed November 1, 2021, https://doi.org/10.3138/ gsi.10.1.03; and Jürgen Zimmerer, "Climate Change, Environmental Violence and Genocide," The International Journal of Human Rights 18, no. 3 (2014), 265-280, accessed November 1, 2021, https://doi.org/ $\underline{10.1080 / 13642987.2014 .914701}$

${ }^{7}$ Importantly, established scholars have promoted the focus on the nature-culture nexus, including Andrew Woolford et al., "We Planted Rice and Killed People:' Symbiogenetic Destruction in the Cambodia Genocide," Genocide Studies and Prevention 15 no. 1 (2021), 44-67, accessed November 1, 2021, https://doi.org/10.5038/1911-9933.15.1.1805; Alex Alvarez, Unstable Ground: Climate Change, Conflict, and Genocide (Lanham: Rowman \& Littlefield Publishers, 2017); and John M. Lanicci et al., eds. Environmental Security Concepts, Challenges, and Case Studies (Chicago: University of Chicago Press, 2019).

8 Kreike, Scorched Earth, 5.

9 Ibid., 32.

10 Ibid., 256-257.

11 Ibid., 366. 
provides clear evidence of the essential role that environcide, the destruction of the local environment, has on the populations being targeted, or the combatants in war. There is no delineation between targeting people, and targeting the environment that allows those people to survive. Such an academic distinction, then, is merely that, as not useful for understanding how war has been waged, and how humans have been impacted by warfare.

The assumptions about the Nature-Culture dichotomy have also impacted how war has been evaluated. War waged against people and their culture has been limited and judged by domestic and international laws that in the modern era seek to prevent and punish war crimes, crimes against humanity, and even genocide. On the other hand, crimes against nature still do not have a formal legal regime that serves to prevent them and punish the perpetrators. ${ }^{12}$ And, as ineffective as the modern anti-genocide regime has been at preventing genocide, the manipulation and destruction of the natural environment as a weapon of war has not even had ineffective regulation.

For example, the traditional focus on the demographic collapse of Native Americans due to their exposure to new diseases has ignored the role that warfare played in creating the conditions that made the people more susceptible to succumbing to those diseases. This displacement model, displacement of people as well as their resources, was common in the cases Kreike provides in this text. Whether it was the smallpox of indigenous Americans, rinderpest in 19th century Sumatra, or the plague in early 20th century Namibia and Angola, targeted populations had their environment degraded so that these diseases had devastating consequences.13 Traditionally, however, the focus on the contagion model has ignored the impact of war on the environment, and then subsequently on people. This is where the dichotomy has limited our understanding of the importance of crimes against the environment as key tactics in warfare, and their indirect, and sometimes direct, role in creating the conditions for genocide.

Kreike argues that "destroying infrastructure... [has] resulted in famines and plagues as lethal and debilitating as such modern weapons of mass destruction as nuclear warheads, napalm, mustard gas, and Zyklon B."14 Thus, his work is within the field of those arguing for a broader understanding of genocide. While environcide was not included in the modern, legal definition of genocide adopted by the U.N., it does fall within Raphael Lemkin's initial understanding of the concept. Though perpetrators may not be attacking the environment of the targeted population with the intent to commit genocide, as required by the Genocide Convention, they are knowingly risking that very outcome by "directly and indirectly exposing people to killer famines, deadly epidemics, and massive refugee displacement." 15 The debate over the definition of genocide is clearly an area of great controversy within the field, but Emmanuel Kreike provides a strong, well-supported argument that human beings have a long history of attacking the environment of their enemies in order to win wars, regardless of, or because of, the effectiveness of this tactic. As we know, genocide is a relatively new concept, but definitely not a new phenomenon. It is only in the modern era that rules of war began to be "controlled" by international law (at Versailles and Nuremberg, for example). Kreike argues that these rules must acknowledge that attacks on the environment are attacks on people, and thus, on human culture, and that such actions should be considered to be both a "crime against humanity and nature." 16

Genocide scholars have long recognized the risks associated with the displacement of people due to warfare. Looking to the present and future, the risks for genocide associated with climate change are linked to the environmental destruction of the past. As our planet warms, and resulting drought and rising sea levels wreak havoc on the most vulnerable, we will likely

\footnotetext{
12 Ibid., 395.

13 Ibid., 395-396.

${ }^{14}$ Ibid., 402.

15 Ibid., 410.

16 Ibid., 417.
} 
see the displacement of huge numbers of people. Kreike's reminder that environcide is a crime in itself, and can have deleterious effects on humanity, should wake up scholars in the field, as well as members of the general public, to the ways in which environmental degradation and destruction will result in the loss of significant human life, as well as unsurprising winners and losers. Rather than view these environmental interactions as marginal or merely supportive factors in causing genocide, scholars in the future may need to readjust their assumptions to see that these factors, and climate change more broadly, will be central to assessing the risks for future mass killing. ${ }^{17}$

17 See also, Mark Levene and Taner Akçam, "The Climate Emergency: A Statement from Genocide Scholars on the Necessity for a Paradigm Shift," Journal of Genocide Research 23 no. 2 (2021), 325-328, accessed November 1, 2021, https://doi.org/10.1080/14623528.2021.1917913. 